\title{
Motivation and Determination of Intention to Become Teacher: A Case of B.Ed. Students in UAE
}

\author{
Taimur Sharif ${ }^{1}$, Chowdhury Golam Hossan ${ }^{2} \&$ Melissa McMinn ${ }^{3}$ \\ ${ }^{1}$ Faculty of Business, ALHOSN University, Abu Dhabi, UAE \\ ${ }^{2}$ College of Business Administration, Abu Dhabi University, Abu Dhabi, UAE \\ ${ }^{3}$ School of Education, Murdoch University, Dubai, UAE \\ Correspondence: Taimur Sharif, Faculty of Business, ALHOSN University, P. O. Box: 38772, Abu Dhabi, UAE. \\ E-mail: t.sharif@alhosnu.ae
}

Received: February 8, 2014

Accepted: March 18, $2014 \quad$ Online Published: April 18, 2014

doi:10.5539/ijbm.v9n5p60

URL: http://dx.doi.org/10.5539/ijbm.v9n5p60

\begin{abstract}
This paper aims to identify key motivational factors and examine the role of gender that influence positively decision to become a teacher in the UAE. Furthermore, due to recent heavy enrolment in teacher education at publicly-funded institutions, this study also finds it essential to understand B.Ed. students' intentions to teach after graduation. A total of 116 pre-service teachers studying in Teachers' Academy in UAE was surveyed using a self-administered questionnaire survey. The data was analysed using multivariate statistical techniques using SPSS. A Likert-type scale with 14 motivational items under four broad categories of motivations, namely, altruistic, intrinsic, extrinsic and pragmatic, was used to accomplish the stated aims of this research. The study confirmed that the intrinsic motivation and altruistic motivation are significant determinant for their intention to become teacher. Extrinsic motivational factors have a very marginal role to play in their decision to teach in the school. The result did not find any significant impact of Pragmatic motivational factors on the intention to teach. Moreover, the results did not find any significant difference between male and female students. These outcomes of the research would be of help for the UAE educators and policymakers. Also, since teachers' education for the Emiraties (UAE nationals) are mostly funded by the government, the findings of this study would be useful in recruiting potential students who have higher possibility to contribute in educational sector of the UAE. To improve the teacher education as well as the recruitment policies and their implications in practice, facilitation of a strong base of 'educational research' in the UAE is recommended. It is important to note that the findings of this study cannot be generalized to the entire UAE teacher education policies and practices due to the small size of the sample available for analysis. Overall, the study provides insights into the motivation factors that prompt greater number of pre-service students to consider teaching as a profession. This would therefore be a useful tool for the UAE educational stakeholders against the backdrop of continuous fall in students' participation.
\end{abstract}

Keywords: teacher education, altruistic, intrinsic, extrinsic, pragmatic, teaching motivation, UAE

\section{Introduction}

"Teachers play a critical role in enabling students to achieve good learning outcomes within effective education systems. While their ability to positively shape a child's learning experience depends on a myriad of factors, the first step towards good learning outcomes is to ensure that there are enough teachers in classrooms" (UNESCO Institute for Statistics-UIS, 2013, pp. 1). On the contrary, at present, 58\% countries of the world are in chronic and persistent short of primary teachers and will require an additional 1.6 million teachers to reach the universal primary education (UPE)-target by 2015 (UIS, 2013). Although this shortage is apparent in all regions of the world, the scenario in Sub-Saharan Africa and Arab region looks even worse. "By 2030, the region will face an explosion in its school-age population with 9.5 million additional students. ... To achieve universal primary education, the region needs to create an additional 500,000 posts by 2030 and replace 1.4 million teachers who will have left the profession" (UNESCO ReliefWeb Report, 2013, pp. 1). The current scenario in the UAE is no exception. For example, in Sharjah, during the period 2008-2012, the number of Emirati teachers has continued to fall, on an average of $16 \%$ per year. Nationally, the fall has been more - a yearly average of $20 \%$ during the same period (Al Rashid, 2013). Altogether, at the national level, currently, the participation of Emiratis in the teaching workforce is only 4\% in general education, and $2 \%$ in secondary schools (Al Rashid, 2013). 
As part of the ongoing educational reforms in the Emirate's public school system, the UAE government has assigned the responsibilities of producing higher quantity of quality teachers on the shoulders of the Ministry of Education (MOE), the Abu Dhabi Education Council (ADEC) and the Dubai Education Council (DEC). At the federal level, the Office of Policy and Planning (OPP) was established to lead educational reforms in the UAE and the MOE was reorganized accordingly. The MOE formulated a series of 5-year plans to achieve the UPE target matching international standards under "Education 2020" mission (Abbas, 2012, p. 1). At the Emirate (state) level, the Abu Dhabi 2030 Vision aimed to have 90 percent Emiratis in education sector by 2030 (Constantinou, 2009). In order to place more Emiratis in key sectors and, thus, reinforce the need for Emiratis to be trained as teachers (Raven, 2011), the UAE government approved four public higher educational institutes (HEIs), e.g., Zayed University, UAE University, Higher Colleges of Technology (the largest HEI in the UAE), and Emirates College for Advanced Education (ECEA), to offer Bachelor of Education (B.Ed.) programmes. The major responsibility of these HEIs has been to prepare future Emirati-teachers to teach in cycle one (grades 1-5) public schools using English as the medium of teaching and learning (T\&L). Despite continuous and large-scale marketing activities, particularly to school leavers, these institutes have not observed much success in terms of motivating their students to choose teaching as the first-choice career. Moreover, from economic point of view, the cost of developing a teacher who eventually leaves the profession is estimated to be thousands of dollars (Sass et al., 2011, pp. 212). It is, as Sinclair et al. (2006) and Mau et al. (2008) argued, now an imperative choice for the UAE educators and policymakers to identify individuals' motivation to pursue teaching careers, understand ways to attract and retain them, and survey their determination to continue teaching. This paper has, therefore, attempted to study the motivational factors in one of the above-cited public HEIs, pseudonymed UAE Teachers' College (UTC).

The plan of this study is as follows: The first section presents theoretical framework and develops hypotheses of the study and ends with a set of research questions. The following section describes the research design and methods. The subsequent section presents the results of empirical data. The final section discusses the outcomes of this study and compares the results with the major findings of the literature, draws conclusions in light of the research questions. This section also highlights the limitations of the study and outlines suggestions for further research.

\section{Theoretical Framework}

\subsection{Intent to Teach: Gender}

Literature (e.g., Richardson \& Watt, 2006; Sinclair, 2008; Bruinsma \& Jansen, 2010; Feng, 2011; Raven, 2011; Dickson \& Le Roux, 2012) in Australia, China, New Zealand, the Netherlands and Turkey suggest that a teaching career suits better with females than males. A study in New Zealand by Livingstone (2002) illustrated growing tendency of male primary school teachers to be the minority due to prioritising other career choices over teaching. In a study among the undergraduate students at the University of Sydney (Australia), Manuel and Hughes (2006) observed more females choosing teaching as first-preference occupation whereas males preferring teaching as second or later career option. Ozturk Akar (2012) also observed: "pre-service teachers are predominantly female, and females are more likely to be attracted to teaching" (p. 16). One of the most cited reasons of choosing teaching as a career in Jarvis and Woodrow (2005) and Williams and Forgasz (2009) is the 'family friendly' feature of the occupation (an intrinsic motivation) - a career that fits in with family life. Brinia (2012, p. 186) argued that women "like working with children" and do "not choose to place themselves in a work situation where they would be unhappy" (altruistic reasons). The participants in Weaver-Hightower's study (2011) cited 'education is a feminine career' as one of the things repeatedly heard by the Emirati male students. In Dickson and Le Roux's (2012) study, the males did not mention this explicitly, but did allude to the pressures felt by the Emirati males as they were often reminded they could get easier jobs that paid more. Dickson and Le Roux's study (2012) also uncovered that half of the male students surveyed expressed that they were not committed to teaching upon graduation and were pursuing B.Ed. purely due to availability of enrolments. Both Dickson and Le Roux and Weaver-Hightower found that male student teachers were subjected to much discouragement from teaching from friends, families and outside parties. However, a few studies (e.g., Goh \& Atputhasamy, 2001, in the context of Singapore) show that females do not have any different motivation than males to enrol in a teaching course and accept teaching jobs.

$\mathrm{H}_{\mathrm{a}} 1$ : There is a difference in preference for teaching between male and female.

$\mathrm{H}_{\mathrm{a}} 2$ : There is a difference in motivation factors between male and female.

\subsection{Intent to Teach: Altruistic and Intrinsic Motivational Factors}

A number of studies have so far been conducted in different parts of the world to identify the motivations that 
influence students to join teaching courses. According to Bastick (2000), Moran et al. (2001) and Goh and Aputhasamy (2001), most types of motivations can be categorised in three scales-extrinsic that covers "hygiene factors" or "lower-order needs" of the Maslow's Theory (Mau et al., 2008, p. 49) such as remuneration, working conditions, social status, etc., intrinsic "that are associated with higher-order needs" of the Maslow's Theory (Mau et al., 2008, pp. 49) such as accomplishment, enjoyment of teaching and the school environment, responsibility, etc. (Sinclair, 2008) as well as altruistic that makes a difference to young lives (Chong and Low, 2009). Among all these, much has been written about altruistic and intrinsic motivations as major reasons to enter teacher training (Al-Yaseen, 2011; Brookhart and Freeman, 1992; Chong \& Low, 2009; Dickson \& Le Roux, 2012; Ejieh, 2005; Hao \& Guzman, 2007; Weaver-Hightower, 2011).

Kyriacou and Coulthard (2000) found that career-change teacher trainees chose teaching because they believed the factors they required from a career could be met by the profession, most importantly having responsibility and making a contribution to society, indicating both intrinsic and altruistic motivations. In a study in Manchester, Jarvis and Woodrow (2005) observed that 93\% of the answers given by the Post Graduate Certificate in Education (PGCE) trainees were of vocational type and had altruistic and intrinsic slants. Krecic and Grmek (2005) who report the main motives of future pedagogy workers were altruistic, including the pursuit of happiness and a wish to work with children, and Williams and Forgasz (2009), whose findings revealed motivations were largely intrinsic. In a more recent study in Kuwait, Al-Yaseen (2011) emphasised altruistic and intrinsic factors as the main influencers to enrol at the College of Education.

$\mathrm{H}_{\mathrm{a}} 3$ : There is a difference in altruistic motivation factors between participants who intent to teach and those who do not intent to teach.

$\mathrm{H}_{\mathrm{a}} 4$ : There is a difference in intrinsic motivation factors between participants who intent to teach and those who do not intent to teach.

\subsection{Intent to Teach: Extrinsic Motivation Factors}

In sharp contrast to intrinsic rewards, there are motivations that are "concerned with the performance of an activity to succeed in getting separable outcomes" (Ryan \& Deci, 2000, p. 71). Ryan and Deci (2000) and Latham (1998) defined these types of motivations as 'extrinsic' and 'tangible benefits' respectively. Hall and Langton (2006) and Suslu (2006) referred to remuneration, fringe benefits, wider opportunities and job security as some good examples of extrinsic motivations. Yong (1995), Papanastasiou and Papanastasiou (1997), Zembylas and Papanastasiou (2004), Williams and Forgasz (2009) and Saiti and Fassoulis (2011) observed that "educators are motivated more by extrinsic motivation than intrinsic" (Saiti \& Fassoulis, 2011, p. 377) in Brunei Darussalam, Cyprus, Greece, Australia and Cyprus respectively. In a study on Filipino student teachers, Hao and Guzman (2007) found that idealistic motivations were later overshadowed by strong extrinsic influences such as the students' desire to work abroad and "explore the globe for greener pastures" (p. 125) as a qualified teacher. Hall and Langton (2006), in their study in New Zealand, conducted twelve focus group interviews among general public and found status of teaching, in the forms of high importance, fame or good image, power or influence, or pay structures, to be a motivational factor. Students in both Ejieh's (2005) study in Nigeria and Dickson and Le Roux's (2012) study in Abu Dhabi (UAE) claimed that the perceived low status of teachers was a major disincentive to enter the teaching profession. In addition to the tangible benefits of teaching, "physical conditions, the amount of work and the facilities available for doing the work are regarded as extrinsic rewards" (Herzberg et al., 1993:49). In an interview conducted by Sharif and McMinn (2013) in the UAE, a number of year 2 B.Ed. students expressed serious concern over the lack of resources they found in Abu Dhabi's cycle one public schools, the amount of work expected of teachers and the length of time teachers spent at school after students were finished for the day. The results of Kane and Mellon (2006) examining the reasons for choosing teaching as a career choice can be used here to reconfirm much of the above findings. However, as a few earlier studies in the UK (Reid and Caudwell, 1997) and the USA (Papanastasiou and Papanastasiou, 1997) claimed extrinsic reasons as relatively less important than altruistic-and intrinsic- ones, the likelihood of the same behaviour would be of interest in the context of this study.

$\mathrm{H}_{\mathrm{a}}$ 5: There is a difference in extrinsic motivation factors between participants who intent to teach and those who do not intent to teach.

\subsection{Intent to Teach: Pragmatic Motivational Factors}

Apart from the above popular types of motivations, there are other reasons (pragmatic) that may play considerable role in teaching-related decision making. For example, in a recent research in Abu Dhabi, Dickson and Le Roux (2012) indicated neither intrinsic nor altruistic motivations behind Emiratis (male) choosing teacher training. Ejieh's (2005) research in Nigeria indicate that a significant percentage of students are simply 
using teachers' college as a way into a university degree programme and have no intention of entering the teaching profession. This also corresponds with the experience of the researchers in this study with students (males, in particular) who required any Bachelor degree to progress further in a current career or to start at a higher rank in a new career, for example, in the UAE police department or UAE army (Sharif \& McMinn, 2013). Similarly, Jarvis and Woodrow (2005) found in the UK that a small minority in the PGCE programme did not intend to teach at all and were merely using the course as a stepping stone to another career. Also disturbing was that approximately $23.5 \%$ of the participants in Williams and Forgasz's (2009) study in Australia, who had returned to higher education specifically to gain a teaching qualification, claimed that they were keeping their work options open.

A number of empirical studies highlighted 'social influences', eg, parents, family members, teachers, peers, etc., as important factors to decide on teaching as a profession. Kyriacou and Coulthard (2000) and Sharif and Jamal-Ena (2002) cited 'dealing with disruptive pupils', 'the amount of bureaucratic tasks to perform' and 'undergoing inspections' as major influencing decision factors to select teaching profession. Referring to Krause et al. (2005), Beltman and Wosnitza (2008, pp. 58) mentioned, "one longitudinal study in Australia found that parental expectations had become increasingly important in students' decisions to undertake tertiary courses in general". Kniveton (2004), Ejieh (2005) and Alastuey et al. (2005) also observed parents' influence in the contexts of England, Nigeria and the USA respectively. Priyadharshini and Robinson-Pant (2003) indicated 'role models (teachers)' as the source of influence in the selection of teaching as a career. However, in the studies done by Lai et al. (2005) and Go and Aputhasamy (2001) in Hong Kong and Singapore respectively, the contributions of social factors were ranked low. One of the reasons behind this finding could be the high social perception about teaching (extrinsic motivation) in these societies where any persuasion is not much required.

$\mathrm{H}_{\mathrm{a}} 6$ : There is a difference in pragmatic motivation factors between participants who intent to teach and those who do not intent to teach.

\subsection{Research Questions}

Research works on motivations to join teacher education and/or teaching are mostly conducted in the contexts of Australia and New Zealand (e.g., Anthony \& Ord, 2008; Mansfield et al., 2011; Nuttal et al., 2006; Richardson \& Watt, 2006), North America (e.g., Papanastasiou and Papanastasiou, 1997; Richardson and Watt, 2010; Sinclair, 2008; Summerhill et al., 1998); Europe, specially Turkey (e.g., Aksu et al., 2010; Aydin \& Baskin, 2005; Boz, 2008; Boz \& Boz, 2008; Grossman, Onkol \& Sands, 2007; Guven, 2008; Ozturk Akar, 2012; Semerci \& Taspinar, 2003). Although a few studies are conducted in the contexts of the middle-east (Al Yaseen, 2011; Raven, 2011; Dickson \& Le Roux, 2012; Yong, 1994; 1995), none of those studies has provided insights into the motivations that prompt the Emirati students to determine their intention to teach in future upon graduation. Abdusheikh (2012), therefore, rightly argued, "while the UAE has implemented several knowledge management initiatives over the past decade, research has not been conducted to examine the impact of these initiatives on Emiratisation" (pp. 20). In this connection, the outcomes of the current case-based research can be of help to fill this research gap. In light of these observations, this research aimed at finding out the factors that initially motivated the current year 1 and 2 Emirati students to enrol at UTC, and checking how many of them, at this stage of their teacher training, do have a plan to teach eventually upon the completion of their teaching course. Accordingly, the research questions of this study were:

1) What proportions of students do intend on entering the teaching profession upon graduation?

2) What are the factors that motivate pre-serve teachers to choose teaching as a profession?

3) Do the answers to the above questions differ for male and female student teachers?

\section{Research Design and Methods}

\subsection{Instrument Development}

In light of the review of literature, a number of items (in the form of statements) were used to check the types of motivations that influence Emiratis to enter teacher education and the teaching profession under three broad scales - intrinsic, extrinsic and altruistic. In view of the prior observations of the researchers on UAE culture as well as literature review, some prominent pragmatic reasons were also taken into consideration for empirical study. These motivations were examined by asking students to rate their reasons for enrolling in a teacher training program and their intentions upon graduation. 
Table 1. List of motivations: summary statistics (Mean, SD, Cronbach's Alpha)

\begin{tabular}{|c|c|c|}
\hline Scale of motivations and items / statements used (Cronbach's Alpha) & Mean & $\begin{array}{l}\text { Standard } \\
\text { Deviation }\end{array}$ \\
\hline \multicolumn{3}{|l|}{ Altruistic (.988) } \\
\hline 1) 'I enjoy working with children' & 4.39 & 0.71 \\
\hline 2) 'I want to be a part of the educational reform in UAE' & 4.26 & 0.88 \\
\hline 3) 'Students need my help in their development' & 3.88 & 1.08 \\
\hline \multicolumn{3}{|l|}{ Intrinsic (.936) } \\
\hline 4) 'I want to share my knowledge with my students' & 4.39 & 0.88 \\
\hline 5) 'I have always wanted to be a teacher' & 3.60 & 1.22 \\
\hline 6) 'Working conditions in schools are good' & 3.87 & 0.93 \\
\hline 7) 'Teaching fits in with family life' - time for family & 3.94 & 0.99 \\
\hline \multicolumn{3}{|l|}{ Extrinsic (.886) } \\
\hline 8) 'The salary for teachers is high/attractive' & 2.66 & 1.09 \\
\hline 9) 'I want to enjoy 3 months of holiday each year' & 3.80 & 1.36 \\
\hline 10) 'Teaching will assure me a job after graduation' & 3.53 & 1.38 \\
\hline 11) 'The teacher has a high status in society' & 3.54 & 1.37 \\
\hline \multicolumn{3}{|l|}{ Pragmatic (.825) } \\
\hline 12) 'I want to obtain a university degree only' & 2.58 & 1.17 \\
\hline 13) 'I want to work in a segregated workplace' & 2.81 & 1.50 \\
\hline 14) 'UTC is an easy college to get into/study at' & 3.48 & 1.05 \\
\hline
\end{tabular}

Notes. 5 = strongly agree; $4=$ agree; $3=$ neither agree nor disagree; $2=$ disagree; $1=$ strongly disagree.

Table 1 above shows the items used to measure each construct (scale of motivations) using 5-point Likert scales completed by participants, means and standard deviations of each item as well as Cronbach's Alpha value of the scales indicating their reliabilities.

\subsection{Data Analysis}

A total 134 pre-service teachers (of B.Ed. years 1 and 2) in UTC were targeted for the survey as part of non-probability (convenience) sampling method. The co-researcher personally administered the survey during a lecture in a core course and, to minimise response bias, took care to ensure participants did not discuss the content with each other. 18 of them were absent on the day of the survey, thus not covered. So, finally, a sample of 116 pre-service teachers was collected with a response rate of $87 \%$. Out of 116 participants, $15 \%(n=17)$ were male and $85 \%(\mathrm{~N}=99)$ were female; $58 \%$ of the students were in the first year of the degree course and $42 \%$ were in the second year; $60 \%(n=69)$ were single, $32 \%(n=37)$ were married, $2.6 \%(n=3)$ were divorced and $6 \%(n=7)$ unknown. The commitment to teach upon graduation was measured by use of an adaptation of Meyer, Allen and Smith's (1993) questionnaire comprising 3 scales: 73\% $(n=85)$ participants have expressed their intention to teach, $26 \%(\mathrm{n}=30)$ no intention to teach and 1 participant did not respond to this question. To ensure that the relations were not attributable to one or a few outliers, the scatterplots were examined. The plots identified a few cases as outliers, thus were removed case wise, and identified no evidence of curvilinear relationship.

\section{Results}

4.1 Intention to Teach upon Graduation: Influence of Gender $\left(H_{a} 1-H_{a} 2\right)$.

The examination results of the cross tabulation between gender and intention to teach show that $80 \%$ of the female participants (99) have expressed their intention to teach and only $20 \%$ respondents opted otherwise (not 
to teach). Of the 17 male respondents, only $40 \%$ intended to join teaching profession and $60 \%$ indicated otherwise. These observations indicated that female candidates are more likely to engage in teaching profession upon completion of B.Ed. degree. Pearson's correlations were performed to test the association between gender and teaching preference. Direct positive correlation has been found between these two variables $(\mathrm{r}=319 ; 95 \%$ confidence interval $.001, .003 ; \mathrm{p}=.001)$. The $95 \%$ confidence interval for correlation $(\mathrm{r}=.319)$ extended from .001 to .003 . Because the null number of " 0 " was not contained inside this interval, $\mathrm{H}_{1} 0$ was rejected. Association between gender-teaching preferences (categorical variable) was further explored using the Chi-square test of association. The frequency distributions of teaching intention scores between two groups differed significantly $\left(\chi^{2}=11.53, d f=1, p=.001\right)$. We examined the practical significance of teaching intention difference between genders and found the effect was large $($ Eta $=0.32)$. Therefore, a decision to reject null-hypothesis was made and concluded that there is a significant difference in preference for teaching between male and female B.Ed. students. In UAE, all local students of B.Ed. are government sponsored. These findings might have a profound impact on their decision making process.

In light of the literature review, t-test analyses were conducted, and the difference between the mean scores of males and females were examined to check whether females have different motivations to choose teaching as a profession than their male counterparts. Levene's test for equality of variance (Homogeneity of variance) was conducted before interpreting the results of t-test. Because the significance were greater than .05 in Levene's test $(0.386 ; 0.897 ; 0.070$; and 0.204), equal variances were assumed. However, we tested for normality of distribution using Kolmogorov-Smirnov test. Instead, Shapiro-Wilk statistical could also be used if we had a smaller sample, ie, 50 or less. In the test of normality, the null hypothesis showed equality between the actual distribution of the variables and the expected distribution. The variable was thus observed to be normally spread. However, the probability associated with the test of normality was observed to be less than or equal to the level of significance (0.01). We, therefore, rejected the null hypothesis and, accordingly, decided that the data set was not normally distributed. We also checked for normality, the skewness and kurtosis for the variables and found that all variables except ALT (Kurtosis 0.030) exceed the rule of thumb criteria of 1.0. The variables are not normally distributed. We reject the null hypothesis and conclude that data set is not normally distributed.

Table 2. Hypothesis test summary

\begin{tabular}{lllll}
\hline Null Hypothesis & Test & Sig. & Decision \\
\hline 1 & $\begin{array}{l}\text { The distribution of ALT is the same across } \\
\text { categories of gender. }\end{array}$ & $\begin{array}{l}\text { Independent Samples } \\
\text { Kruskal-Wallis Test }\end{array}$ & .543 & $\begin{array}{l}\text { Retain the null } \\
\text { hypothesis. }\end{array}$ \\
2 & $\begin{array}{l}\text { The distribution of INT is the same across } \\
\text { categories of gender. }\end{array}$ & $\begin{array}{l}\text { Independent Samples } \\
\text { Kruskal-Wallis Test }\end{array}$ & .919 & $\begin{array}{l}\text { Retain the null } \\
\text { hypothesis. }\end{array}$ \\
3 & $\begin{array}{l}\text { The distribution of EXT is the same across } \\
\text { categories of gender. }\end{array}$ & $\begin{array}{l}\text { Independent Samples } \\
\text { Kruskal-Wallis Test }\end{array}$ & .574 & $\begin{array}{l}\text { Retain the null } \\
\text { hypothesis. }\end{array}$ \\
4 & $\begin{array}{l}\text { The distribution of PRA is the same across } \\
\text { categories of gender. }\end{array}$ & $\begin{array}{l}\text { Independent Samples } \\
\text { Kruskal-Wallis Test }\end{array}$ & .882 & $\begin{array}{l}\text { Retain the null } \\
\text { hypothesis. }\end{array}$ \\
\hline
\end{tabular}

Notes. Asymptotic significances are displayed. The significance level is .05.

Because parametric testing was not justified, non-parametric tests (Kruskal-Wallis) were conducted (Table 1). The result shows that there is no significant difference in motivation between male and female participants.

\subsection{Intention to Teach and Not Teach upon Graduation: Difference in Motivation Factors $\left(\mathrm{H}_{a} 3-\mathrm{H}_{a} 6\right)$.}

Levene's test for equality of variance (Homogeneity of variance) was conducted before interpreting the results of t-test. Because the significances were greater than .05 in Levene's test $(0.570 ; 0.320 ; 0.973$; and 0.640$)$, equal variances were assumed. 
Table 3. Test of homogeneity of variances

\begin{tabular}{lllll}
\hline & Levene Statistic & df1 & df2 & Sig. \\
\hline Altruistic motivation & 2.049 & 1 & 102 & .155 \\
Intrinsic motivation & 3.533 & 1 & 102 & .063 \\
Extrinsic motivation & .492 & 1 & 102 & .485 \\
Pragmatic motivation & .357 & 1 & 102 & .551 \\
\hline
\end{tabular}

An independent sample t-test showed that students intend to teach have significantly higher altruistic motivation $(\mathrm{n}=84, \mathrm{M}=4.45, \mathrm{SD}=.55)$ than students who do not intend to teach $(\mathrm{n}=29, \mathrm{M}=4.1015, \mathrm{SD}=.55396), \mathrm{t}=$ $2.986, \mathrm{p}<.01$. In order to understand practical significance of mean difference, we have calculated effect size using Cohen's $d(0.63)$ and effect-size $r(0.30)$ with a moderate degree of effect.

Table 4. Difference in motivation factors between intention to teach and not teach

\begin{tabular}{lccccc}
\hline & $\mathrm{N}$ & Mean & $\mathrm{SD}$ & $\mathrm{T}$ & Sig.(2-tailed) \\
\hline Altruistic motivation & & & & .003 \\
Teach & 84 & 4.4584 & .55542 & & \\
Not Teach & 29 & 4.1015 & .55396 & & \\
Intrinsic motivation & & & & & \\
Teach & 84 & 4.1111 & .64944 & & .004 \\
Not Teach & 29 & 3.6874 & .70311 & & \\
Extrinsic motivation & & & & & .106 \\
Teach & 84 & 3.6546 & .67164 & & \\
Not Teach & 29 & 3.4165 & .69584 & & .794 \\
Pragmatic motivation & & & & & \\
Teach & 84 & 3.2016 & .71376 & & \\
Not Teach & 29 & 3.2411 & .66396 & & \\
\hline
\end{tabular}

An independent sample t-test showed that students who intend to teach have significantly higher intrinsic motivation ( $\mathrm{n}=84, \mathrm{M}=4.11, \mathrm{SD}=.65$ ) than students who do not intend to teach $(\mathrm{n}=29, \mathrm{M}=3.68, \mathrm{SD}=.70), \mathrm{t}=$ $2.966, \mathrm{p}<.01$. We have calculated effect sizes using Cohen's $\mathrm{d}(0.63)$ and effect-size $\mathrm{r}(0.30)$, and found a moderate degree of effect.

An independent sample t-test showed that students who intend to teach have higher extrinsic motivation $(\mathrm{n}=84$, $\mathrm{M}=3.65, \mathrm{SD}=.67)$ than students who do not intend to teach $(\mathrm{n}=29, \mathrm{M}=3.41, \mathrm{SD}=.69), \mathrm{t}=1.631, \mathrm{p}<.10$. However, this mean difference is significant only at $90 \%$ confidence level. In other words, significance test has marginally failed to meet $p<.05$. There is an overall drop in mean value in extrinsic motivation. The final motivation factor, ie, pragmatic, has failed to show any significance affect.

In summary, altruistic motivations and intrinsic motivations are significantly higher among participants who intend to teach than those who do not intend to teach. Extrinsic motivation is higher among the participants who intend to teach but statistically significant only marginally. Pragmatic motivation has no significant effect on participant's decision to teach or not. This finding integrates motivation to further examine those variables. However, before proceed to further analysis, a non-parametric test (Kruskal-Wallis) was conducted to reconfirm our findings (Table 5). 
Table 5. Hypothesis test summary

\begin{tabular}{|c|c|c|c|c|}
\hline & Null Hypothesis & Test & Sig. & Decision \\
\hline 1 & $\begin{array}{l}\text { The distribution of ALT is the same across } \\
\text { categories of Teach. }\end{array}$ & $\begin{array}{l}\text { Independent Samples } \\
\text { Kruskal-Wallis Test }\end{array}$ & .001 & $\begin{array}{l}\text { Reject the null } \\
\text { hypothesis. }\end{array}$ \\
\hline 2 & $\begin{array}{l}\text { The distribution of INT is the same across } \\
\text { categories of Teach. }\end{array}$ & $\begin{array}{l}\text { Independent Samples } \\
\text { Kruskal-Wallis Test }\end{array}$ & .005 & $\begin{array}{l}\text { Reject the null } \\
\text { hypothesis. }\end{array}$ \\
\hline 3 & $\begin{array}{l}\text { The distribution of EXT is the same across } \\
\text { categories of Teach. }\end{array}$ & $\begin{array}{l}\text { Independent Samples } \\
\text { Kruskal-Wallis Test }\end{array}$ & .152 & $\begin{array}{l}\text { Retain the null } \\
\text { hypothesis. }\end{array}$ \\
\hline 4 & $\begin{array}{l}\text { The distribution of PRA is the same across } \\
\text { categories of Teach. }\end{array}$ & $\begin{array}{l}\text { Independent Samples } \\
\text { Kruskal-Wallis Test }\end{array}$ & .703 & $\begin{array}{l}\text { Retain the null } \\
\text { hypothesis. }\end{array}$ \\
\hline
\end{tabular}

Notes. Asymptotic significances are displayed. The significance level is .05.

The correlation matrix contains 10 bivariate correlations that were computed among study's five variables (Table 4). Correlation between teaching preference and altruistic motivation yielded results of $r=.344(p<.01)$. Correlation between teaching preference and intrinsic motivation yielded results of $r=.301(p<.01)$. Altruistic motivation and intrinsic motivation are also positively related significantly $(\mathrm{r}=.291 \mathrm{p}<.01)$. The sizes of effects for all correlations are medium.

Table 6. Pearson's correlations

\begin{tabular}{llllll}
\hline & Teach & ALT & INT & EXT & PRA \\
\hline Teach & 1 & & & & \\
Altruistic motivation & $.344^{* *}$ & 1 & & & \\
Intrinsic motivation & $.301^{* *}$ & $.291^{* *}$ & 1 & & \\
Extrinsic motivation & .118 & .185 & .187 & 1 & $.236^{*}$ \\
Pragmatic motivation & -.040 & -.060 & -.121 & 1 \\
\hline
\end{tabular}

Notes. a. Listwise $\mathrm{N}=104, *$ Significant at 0.05 and $* * 0.01$ levels (2-tailed), respectively.

A binary logistic regression was used to explore what motivational factors could predict preference to teach of B.Ed. students. In the final model, both altruistic motivation and intrinsic motivation were a significant predictor of teaching preference among B.Ed. students, with altruistic motivation $\left(B=1.314\right.$; Walid's $\left.\chi^{2}=7.07, \mathrm{p}<.01\right)$ recording a higher beta value than intrinsic motivation $\left(\mathrm{B}=1.098\right.$; Walid's $\left.\chi^{2}=5.91, \mathrm{p}<.05\right)$. The model explained $24.4 \%$ (Nagelkerke's $R^{2}$ ) of the variance in teaching preference and correctly classified $75.5 \%$ of cases, with a sensitivity of $25 \%$ and a specificity of $92.7 \%$ where cases with a .50 or greater predicted probability were classified as affected.

\section{Discussion and Conclusions}

The overall findings of this study support Sinclair's (2008) conclusion that student teachers have multiple motivations to teach. The logistic regression used in this study to identify determining factor for intention to teach found that Altruistic motivation is the most important determinant of intention to become teacher, and supported the findings of Chong and Low (2009), Doliopoulou (1995), Goh and Atputhasamy (2001), Hayes (1990), Lau (1968), Ok and Onkol (2007), Ozturk Akar (2012), Reid and Caudwell (1997), Robertson et al. (1983), Soh (1981, 1989), Summerhill et al. (1998), among others. The logistic regression also found intrinsic motivation to be the second most important determinant of intention to become teacher and reinforced the observations of Anthony and Ord (2008), Manuel and Hughes (2006), Ok and Onkol (2007), Papanastasiou and Papanastasiou (1997), Summerhill et al. (1998), among others. This model explained nearly 25 percent of variance in teaching preference. In other words, altruistic motivation and intrinsic motivations control and predict 25 percent of variance in preference of teaching profession of students of B.Ed. programme in the UAE.

Previous literature (e.g., Sass et al., 2011) pinpointed the importance of investing heavily to develop a student as a professionally qualified/educated teacher. As found in this study, three quarter of the B.Ed. students are intending to teach - probably a positive news for the UAE educators. However, critiques may argue that B.Ed., like medical, engineering, etc., is a specialized education where only focus is to get students ready for teaching 
career. Twenty six percent students indicated that they are not considering teaching as a career option, that is, one in every four potential B.Ed. graduates will not contribute in the UAE education - a sector where B.Ed. study by the UAE-nationals are publicly-funded and still suffers from a serious shortage of qualified teachers (Constantinou, 2009; Raven, 2011; Al Rashid, 2013). In this situation, losing more than 25 percent qualified teachers is certainly an issue of high concern. This study has examined distribution of teaching intention across gender and found that majority of female students are likely to join teaching profession after graduation. The participants in these studies cited 'education is a feminine profession' as one of the repeatedly heard things. The association between female students and intention to teach is positively related and statistically significant. This finding supported the observations of Richardson and Watt (2006), Sinclair (2008), Bruinsma and Jansen (2010), Feng (2011), Weaver-Hightower (2011), Ozturk Akar (2012), among others, and not supported Goh and Aputhasamy (2001). Resemblant to Dicken and Le Roux (2012), an alarming finding of this study is the confirmation of $60 \%$ of male students that they will not join teaching profession. Further study, especially of qualitative nature, is needed to identify why majority of male students are not willing to join teaching profession in a situation where demands for teachers are high and they will have qualification to meet that demand.

As the major reasons for entering the teacher education programme at UTC, a significant percentage (at least or above $84 \%$ ) of the B.Ed. years 1 and 2 student body agreed or strongly agreed on certain intrinsic and altruistic motivations, and, thus, reiterated the empirical findings of Lau (1968), Soh (1981 and 1998), Robertson et al. (1983), Hayes (1990), Doliopoulou (1995), Reid and Caudwell (1997), Summerhill et al. (1998) and Goh and Atputhasamy (2001) in the contexts of Asia, Europe and the US. Among altruistic reasons, this study concludes that students who enjoy working with children are more likely to select teaching as a career, thus, reiterates the finding of Brinia (2012). This might be also a natural explanation for the gender difference in teaching preference - females are more likely to become teacher. This study also found that a feeling that someone can be a part of important change of the country such as education also motivates student to become teacher. Important to note that this finding is not only statistically important but it has also a moderate degree of practical significance for relevant stakeholders. Furthermore, this study also found that intrinsic motivation is significantly higher in the group of students who intend to teach compared to the other group. So, intrinsic motivation mostly deals with student's attitude towards teaching career. This study concludes that students who see teaching as a noble profession where they can share their knowledge, and perceived a good fit to life style are more likely to join teaching profession. This finding has a moderate degree of practical significance for relevant policy makers. The bivariate correlation analysis confirms that teaching preference and altruistic motivation has a highly significant positive relationship. Correlation between teaching preference and intrinsic motivation has found positive relationship. Altruistic motivation and intrinsic motivation are also positively related and it is statistically significant. It indicates that focusing on altruistic motivation and intrinsic motivation will result in more students becoming teachers after graduation.

The importance of extrinsic reasons to join teaching is highlighted in Boz and Boz (2008), Ok and Onkol (2007) and Ozbek (2007) in Turkey. Reid and Caudwell (1997), however, indicated extrinsic motivations as very important but relatively less significant than altruistic and intrinsic reasons in the context of the UK. The overall observation on extrinsic reasons in this study is no exception. This study found that extrinsic motivation has very marginal influence on students' decision to become teachers. Moreover, there is an overall drop in mean score in extrinsic motivation probably meaning teaching profession is not much rewarding in UAE compared to other profession. On top of this, standardisation requirements by the UAE Ministry of Education (e.g., 'the amount of bureaucratic tasks to perform', 'undergoing inspections', etc.) are making teaching profession more stressful-a powerful source of demotivation to teach (Kyriacou \& Coulthard, 2000; Rots et al., 2010). It is still not clear how teaching profession is being regarded in the UAE local culture. Presence of lucrative extrinsic motivation factors such as high salary (Hall \& Langton, 2006; Suslu, 2006), high social status (Dickson and Le Roux, 2012; Ejieh, 2005; Hall \& Langton, 2006; Morales, 2007) are pre-requisites to attract competent candidates in an important profession like teaching. Educators and policy makers may need to consider this aspect with urgency.

Ejieh (2005), Jarvis and Woodrow (2005), Hao and de Guzman (2007), and Williams and Forgasz (2009) indicated that a significant percentage of students simply use teacher training for pragmatic reasons. In the case of UTC, pragmatic motivations had a little impact, particularly working in a segregated workplace for females and the college being easy to get into for the coveted male students. However, overall, this study did not find any significant effect of pragmatic motivational factors on student's decision-making. As newly developed scale, pragmatic motivational scale used in this study has an acceptable reliability score. This scale may need to be used in further studies to examine its significance. The bivariate correlation analysis confirms that extrinsic motivation and pragmatic motivation are positively correlated indicating (a) an increase of one factor will result 
in positive increase in other factor and (b) teaching profession needs more attention from economic and social perspective. This may be emphasized here that having higher salary in teaching profession will result in higher acceptance of teaching profession in the society and vice-versa.

Interestingly, more males (64\% of their total) than females ( $57 \%$ of their total) were found to be altruistically motivated by always wanting to be a teacher but, in terms of choosing to pursue a teaching career upon graduation, it was males who appeared more undecided. However, it was encouraging to notice that more students enrolled with (at least) an initial motivation to enter the teaching profession. In order to nurture this motivation throughout the teacher training period, as Sinclair (2008) argued, it is important to ensure that a combination of intrinsic, extrinsic and altruistic motivations, eg, the experience of working with and having influence over children in schools, the working conditions, students experience, seeing their suitability as teachers through self-evaluations, from feeling valued to making a difference in the world, significant change in the perception of teaching, a transparent promotions path, etc., does play a solid role in increasing their commitments to teach. These recommendations can be treated as valuable for policy-making at the higher education level, the state/Emirates levels (e.g., Abu Dhabi Education Council, Dubai Knowledge and Human Development Authority, etc.) and the UAE national level (e.g., National HR Development and Employment Authority), thus, allowing provisions to attract and retain more UAE-nationals into teaching at the school level.

Of course, a higher possibility to pursuing for a teaching career on a questionnaire does not actually mean student teachers will remain equally motivated to end up choosing teaching as a career. This study, therefore, recommends further researches:

(a) To look into the intentions of the same cohort (of this study) to teach on the verge of their graduation in two years' time, and see if these percentages have shifted significantly to a different horizon of career-thoughts.

(b) To see whether the ongoing educational reforms on UAE-public schools attract more nationals to teaching as a career, thus fasten the process of Emiratising the workforce.

(c) To check whether Emirati (UAE-national) student teachers who are studying in private universities on self-finance have different motivations and teaching commitments than their counterparts studying in public universities free of cost.

(d) To analyze those factors dissuading potential student teachers from the profession.

Moreover, as this study failed to make any conclusion whether the difference of preferences in teaching between male and female students has been subject to influence of motivational factors covered in this study, further study can be suggested to identify the gender-specific factors that influence their decision to become professional teachers. Finally, as this study is based on a small sample from Abu Dhabi (the capital and the most affluent Emirate/state of UAE), the research findings cannot be generalized to the entire UAE teacher education policies and practices. Analysis of additional data covering more teacher training institutes from different Emirates will, therefore, be required for isolation of the significant variances in motivations and validation of the outcomes of this research across Emirates.

\section{References}

Abbas, S. N. (2012). Teacher Leadership and Educational Reforms in UAE. Global Journal of Management and Business Research, 12(22), 1-4.

Abdusheikh, M. (2012). Emiratization: United Arab Emirates' National Workforce Development Program. MSc Research Project, School of Business and Management, Pepperdine University.

Aksu, M., Engin-Demir, C., Daloglu, A., Yildirim, S., \& Kiraz, E. (2010). Who are the future teachers in Turkey? Characteristics of entering student teachers. International Journal of Educational Development, 30(1), 91-101. http://dx.doi.org/10.1016/j.ijedudev.2009.06.005

Al Rashid, A. M. (2013, March 24). More Emirati teachers needed in Sharjah schools. Khaleej Times. Retrieved from http://www.khaleejtimes.com/nation/

Al Yaseen, W. S. (2011). Factors Influencing Kuwaiti Student Teachers' Choice of Teaching as a Profession. College Student Journal, 45(3), 667-680.

Alastuey, L., Justice, M., Weeks, S., \& Hardy, J. (2005). Why we complete a teacher education program — credentialed teachers: A critical incident inquiry. Education, 126(1), 37-47.

Anthony, G., \& Ord, K. (2008). Change-of-career secondary teachers: motivations, expectations and intentions. Asia Pacific Journal of Teacher Education, 36(4), 359-376. http://dx.doi.org/10.1080/13598660802395865 
Aydin, A., \& Baskin, G. A. (2005). The problem of teacher training in Turkey. Biotechnology \& Biotechnological Equipment, 19(2), 191-198.

Bastick, T. (2000). Why teacher trainees choose the teaching profession: Comparing trainees in metropolitan and developing countries. International Review of Education, 6(3), 343-349.

Beltman, S., \& Wosnitza, M. (2008). You are getting too old, find a man and marry: Social Aspects of Motivation to Choose Teacher Education. Australian Journal of Educational \& Developmental Psychology, $8,49-63$.

Boz, Y. (2008). Turkish students teachers' concerns about teaching. European Journal of Teacher Education, 31(4), 367-377.

Boz, Y., \& Boz, N. (2008). Chemistry and mathematics pre-service teachers' reasons to choose teaching. Kastamonu Education Journal, 16(1), 137-144.

Brinia, V. (2012). Men vs women; educational leadership in primary schools in Greece: an empirical study. International Journal of Educational Management, 26(2), 175-191. http://dx.doi.org/10.1108/09513541211201988

Brookhart, S. M., \& Freeman, D. J. (1992). Characteristics of entering teacher candidates. Review of Educational Research, 62(1), 37-60. http://dx.doi.org/10.3102/00346543062001037

Bruinsma, M., \& Jansen, E. P. W. A. (2010). Is the motivation to become a teacher related to pre-service teachers' intentions to remain in the profession? European Journal of Teacher Education, 33(2), 185-200.

Chong, S., \& Low, E. L. (2009). Why I want to teach and how I feel about teaching-formation of teacher identity from pre-service to the beginning teacher phase. Educational Research Policy and Practice, 8(1), 59-72. http://dx.doi.org/10.1007/s10671-008-9056-z

Constantinou, H. (2009). Reflectionin Education: An Exploration of EFL Teachers' Conceptions of Reflective Practice in the UAE. PhD thesis, University of Exeter.

Dickson, M., \& Le Roux, J. (2012). Why do Emirati males become teachers and how do cultural factors influence this decision? Learning and Teaching in Higher Education: Gulf Perspectives, 9(2), 1-16.

Doliopoulou, E. (1995). The motives for the selection of the teaching profession by future kindergarten teachers and the factors which form their later opinion of their profession. International Journal of Early Childhood, 27(1), 28-33. http://dx.doi.org/10.1007/BF03178102

Ejieh, M. U. C. (2005). Students' reasons for entering Nigerian primary teacher education and their career plans. Research in Education, 74(1), 36-47. http://dx.doi.org/10.7227/RIE.74.4

Feng, Y. (2011). Teacher career motivation and professional development in special and inclusive education: perspectives from Chinese teachers. International Journal of Inclusive Education, 16(3), 331-351. http://dx.doi.org/10.1080/13603116.2010.489123

Goh, K. C., \& Aputhasamy, L. (2001). Teacher education in Singapore: What motivates students to choose teaching as a career? paper presented at International Educational Research Conference, 2-6 December, University of Notre Dame, Australia.

Grossman, G. M., Onkol, P. E., \& Sands, M. (2007). Curriculum reform in Turkish teacher education: Attitudes of teachers educators towards change in an EU candidate nation. International Journal of Educational Development, 27(2), 138-150. http://dx.doi.org/10.1016/j.ijedudev.2006.07.005

Guven, I. (2008). Teacher education reform and international globalization hegemony: Issues and challenges in Turkish teacher education. International Journal of Human and Social Sciences, 3(1), 8-18.

Hall, D., \& Langton, B. (2006). Perceptions of the status of teachers. Wellington: Ministry of Education.

Hao, A., \& de Guzman, A. B. (2007). Why go into teaching? Understanding Filipino preservice teachers' reasons for entering teacher education. Journal of Educational Policy, 4(2), 115-135.

Hayes, S. (1990). Students' reasons for entering the educational profession. Research Report, Oklahoma: North-western Oklahoma State University.

Herzberg, F., Mausner, B., \& Snyderman, B. B. (1993). The Motivation to Work. New Jersey: Transaction Publishers.

Jarvis, J., \& Woodrow, D. (2005). Reasons for choosing a teacher training course. Research in Education, 73, 


\section{9-35. http://dx.doi.org/10.7227/RIE.73.3}

Kane, R. G., \& Mallon, M. (2006). Perceptions of teachers and teaching. Wellington: Ministry of Education.

Kniveton, B. H. (2004). The influences and motivations on which students base their choice of career. Research in Education, 72, 47-61. http://dx.doi.org/10.7227/RIE.72.4

Krause, K. L., Hartley, R., James, R., \& McInnes, C. (2005). The first year experience in Australian universities: Findings from a decade of national studies. Retrieved from http://www.dest.gov.au/sectors/higher_education/publications_resources/profiles/first_year_experience.htm \#version

Krecic, M., \& Grmek, M. (2005). The reasons students choose teaching professions. Educational Studies, 31, $265-274$.

Kyriacou, C., \& Coulthard, M. (2000). Undergraduates' views of teaching as a career choice. Journal of Education for Teaching, 26(2), 117-126. http://dx.doi.org/10.1080/02607470050127036

Lai, K. C., Chan, K. W., \& So, K. S. (2005). Teaching as a career: A perspective from Hong Kong senior secondary students. Journal of Education and Teaching, 31(3), 153-168. http://dx.doi.org/10.1080/02607470500168974

Latham, A. S. (1998). Teacher Satisfaction. Educational Leadership, 55, 82-83.

Lau, W. H. (1968). Why teach? A study of motives for teaching as a career, Singapore Teachers' Training College. Unpublished paper, Institute of Education, Singapore.

Livingstone, I. (2003). Going, going ....? Men in primary teaching in New Zealand. New Zealand Annual Review of Education, 12, 39-74.

Mansfield, C. F., Beltman, S., \& Wosnitza, M. (2011). Goals for teaching: A goal content approach to understanding teacher motivation. Paper presented at the biannual conference of the European Association for Research in Learning and Instruction (EARLI), 29 September-3 October, Exeter, UK.

Manuel, J., \& Hughes, J. (2006). It has always been my dream: exploring pre-service teachers' motivations for choosing to teach. Teacher Development, 10(1), 5-24.

Mau, W. C. J., Ellsworth, R., \& Hawley, D. (2008). Job satisfaction and career persistence of beginning teachers. International Journal of Educational Management, $22(1), \quad 48-61$. http://dx.doi.org/10.1108/09513540810844558

McNamara, P. M., Moynihan, S., Jourdan, D., \& Lynch, R. (2012). Pre-service teachers' experience of and attitudes to teaching SPHE in Ireland. Health Education, 112(3), 199-216.

Meyer, J. P., Allen, N. J., \& Smith, C. A. (1993). Commitment to organizations and occupations: Extension and test of a three-component conceptualization. Journal of Applied Psychology, 78(4), 538-551. http://dx.doi.org/10.1037//0021-9010.78.4.538

Moran, A., Kilpatrick, R., Abbot, L., Dallat, J., \& McClune, B. (2001). Training to teach: Motivating factors and implications for recruitment. Evaluation and Research in Education, 15(1), 17-32. http://dx.doi.org/10.1080/09500790108666980

Nuttal, J., Murray, S., Seddon, T., \& Mitchell, J. (2006). Changing research context in teacher education in Australia: charting new directions. Asia Pacific Journal of Teacher Education, 34(3), 321-332. http://dx.doi.org/10.1080/13598660600927224

Ok, A., \& Önkol, P. (2007). The Profile of Prospective Teachers in Teacher Education Programs. Education and Science, 32(143), 13-26.

Ozbek, R. (2007). Teacher candidates' perceptions of personal, economical and social factors influencing their decisions to become teachers. Firat University Journal of Social Sciences, 9(2), 221-233.

Ozturk Akar, E. (2012). Motivations of Turkish Pre-Service Teachers to Choose Teaching as a Career. Australian Journal of Teacher Education, 37(10). http://dx.doi.org/10.14221/ajte.2012v37n10.7

Pananastasiou, C., \& Papanastasiou, E. (1997). Factors that influence students to become teachers. Educational Research and Evaluation, 3(4), 305-316.

Priyadharshini, E., \& Robinson-Pant, A. (2003). The attractions of teaching: An investigation into why people change careers to teach. Journal of Education for Teaching, 29(2), 95-112. 
http://dx.doi.org/10.1080/0260747032000092639

Raven, J. (2011). Emiratizing the education sector in UAE: contextualization and challenges. Education, Business and Society: Contemporary Middle Eastern Issues, 4(2), 134-141. http://dx.doi.org/10.1108/17537981111143864

Reid, I., \& Caudwell, J. (1997). Why did secondary PGCE students choose teaching as a career? Research in Education, 58, 46-58.

Relief Web Report. (2013). World: UNESCO study shows Africa and Arab States are worst hit by teacher shortage. UN Educational, Scientific and Cultural Organization. Retrieved from http://reliefweb.int/report/world/unesco-study-shows-africa-and-arab-states-are-worst-hit-teacher-shortage\# sthash.2ur1E7As.dpuf

Richardson, P. W., \& Watt, H. M. G. (2006). Who chooses teaching and why? Profiling characteristics and motivations across three Australian universities. Asia-Pacific Journal of Teacher Education, 34(1), 27-56. http://dx.doi.org/10.1080/13598660500480290

Richardson, P. W., \& Watt, H. M. G. (2010). Current and future directions in teacher motivation research. In T. Urdan \& S. A. Karabenick (Eds.), The Decade Ahead: Applications and Contexts of Motivation and Achievement. UK: Emerald. http://dx.doi.org/10.1108/S0749-7423(2010)000016B008

Robertson, S. D., Keith, T. A., \& Page, E. B. (1983). Now who aspires to teach? Educational Researcher, 12(6), $13-20$.

Rots, I., Aelterman, A., Devos, G., \& Vlerick, P. (2010). Teacher education and the choice to enter the teaching profession: A prospective study. Teaching and Teacher Education, 26(8), 1619-1629. http://dx.doi.org/10.1016/j.tate.2010.06.013

Ryan, R. M., \& Deci, E. L. (2000). Self-Determination Theory and the Facilitation of Intrinsic Motivation, Social Development and Well-Being. American Psychologist, 55(1), 68-78. http://dx.doi.org/10.1037//0003-066X.55.1.68

Saiti, A., \& Fassoulis, K. (2011). Job satisfaction: factor analysis of Greek primary school principals' perceptions. International Journal of Educational Management, 26(4), 370-380.

Sass, D. A., Seal, A. K., \& Martin, N. K. (2011). Predicting teacher retention using stress and support variables. Journal of Educational Administration, 49(2), 200-215. http://dx.doi.org/10.1108/09578231111116734

Semerci, Ç., \& Tapınar, M. (2003). Restructuring of the teacher training system in Turkey. Kyrgzstan-Turkish Manas University Social Sciences Journal, 37(6), 137-146.

Sharif, T., \& Jamal, E. S. (2002). Human Resource Mobility: An Analytical Study on the Private University Teachers of Bangladesh. AIUB Journal of Business and Economics, 1(2), 60-81.

Sharif, T., \& McMinn, M. (2013). Development of Endogenous Teaching Workforce in the UAE: A Case Study of the Motivation of Emiratis to Become Teachers. Proceedings of the Annual Conference of Management and Social Sciences (ACMSS), Bangkok, Thailand, 16-18 April.

Sinclair, C. (2008). Initial and changing student teacher motivation and commitment to teaching. Asia-Pacific Journal of Teacher Education, 36(2), 79-104. http://dx.doi.org/10.1080/13598660801971658

Sinclair, C., Dowson, M., \& McInerney, D. M. (2006). Motivations to teach: Psychometric perspectives across the first semester of teacher education. Teachers College Record, 108(6), 1132-1154. http://dx.doi.org/10.1111/j.1467-9620.2006.00688.x

Soh, K. C. (1981). Student profiles and motives for teaching of full-time students in the institute of education. Occasional paper No. 7, Singapore: Institute of Education.

Soh, K. C. (1989). Motives for Teaching of Female Certificate in Education Students. Research Paper ERU/9/89, Singapore: Institute of Education.

Summerhill, A., Matranga, M., Peltier, G., \& Hill, G. (1998). High school seniors' perception of a teaching career. Journal of Teacher Education, 49(1), 228-232.

Suslu, S. (2006). Motivation of ESL Teachers. The Internet TESL Journal, 12(1),

UNESCO Institute for Statistics (UIS). (2013). A teacher for every child: Projecting Global Teacher Needs from 2015 to 2030. 
Weaver-Hightower, M. (2011). Male Preservice Teachers and Discouragement from Teaching. Journal of Men's Studies, 19(2), 97-115. http://dx.doi.org/10.3149/jms.1902.97

Williams, J., \& Forgasz, H. (2009). The motivations of career change students in teacher education. Asia-Pacific Journal of Teacher Education, 37(1), 95-108. http://dx.doi.org/10.1080/13598660802607673

Yong, C. S. (1994). Factors that determine the attractiveness of the teaching profession in Brunei Darussalam. Journal of Education and Teaching, 20(1), 113-126. http://dx.doi.org/10.1080/0260747940200112

Yong, C. S. (1994/1995). Teacher trainee's motives entering into a teaching career in Brunei Darussalam. Teaching and Teacher Education, 11(3), 275-280.

Zembylas, M., \& Papanastasiou, E. (2004). Job satisfaction among school teachers in Cyprus. Journal of Educational Administration, 42(3), 357-374. http://dx.doi.org/10.1108/09578230410534676

\section{Copyrights}

Copyright for this article is retained by the author(s), with first publication rights granted to the journal.

This is an open-access article distributed under the terms and conditions of the Creative Commons Attribution license (http://creativecommons.org/licenses/by/3.0/). 